\title{
The International Academy of Sex Research: In the Beginning
}

\section{Richard Green}

Published online: 22 February 2008

(C) Springer Science+Business Media, LLC 2008

Erratum to: Arch Sex Behav (1985) 14(4)

DOI 10.1007/BF01550845

In this article, under the list of charter members of the International Academy of Sex Research, the following member was inadvertently omitted: Volkmar Sigusch. The author regrets this error.

The online version of the original article can be found under doi:10.1007/BF01550845.

R. Green $(\varangle)$

Department of Psychological Medicine, Imperial College at Charing Cross Hospital, London W6 8LN, England

e-mail: richard.green@ic.ac.uk 